\title{
Stanisław Sala
}

Uniwersytet Jana Kochanowskiego w Kielcach

Instytut Geografii i Nauk o Środowisku

ssala@ujk.edu.pl

\section{Wpływ procesów globalizacji na zmiany przestrzeni miejskiej Kielc}

\begin{abstract}
Zarys treści: Jednym z głównych czynników warunkujących rozwój współczesnych miast są procesy globalizacji. $Z$ jednej strony coraz silniej wiążą ze sobą tendencje globalne $z$ kwestiami lokalnymi, natomiast $z$ drugiej strony eliminują pewne obszary z głównego nurtu rozwoju. W pracy przedstawiono inicjatywy podjęte w Kielcach pod wpływem tych procesów. We wstępnych rozdziałach omówiono specyfikę transformacji gospodarczej Kielc oraz zmiany w fizjonomii miasta będące konsekwencją usunięcia barier gospodarczych i fizjonomicznych ze światem zewnętrznym, a następnie rozwój: korporacji handlowych, nowoczesnych usług dla biznesu, nowoczesnych powierzchni wystawienniczych i Kieleckiego Parku Technologicznego, będących przykładami glokalizacji.
\end{abstract}

Słowa kluczowe: procesy globalizacji, rozwój lokalny, rozwój społeczno-gospodarczy, Kielce

\section{Wprowadzenie}

Zasięg procesów globalizacji jest nierównomierny i fragmentaryczny - nie obejmują one ani wszystkich państw świata, ani nawet całych państw. W poszczególnych państwach procesy globalizacji obejmują głównie ośrodki miejskie oraz ich najbliższe otoczenie. Miasta, w zależności od ich skali, są lokalnymi, regionalnymi, krajowymi, kontynentalnymi i światowymi biegunami wzrostu. Przyciągają światowe instytucje finansowe, korporacje transnarodowe lokują w nich bezpośrednie inwestycje zagraniczne, powstają nowe struktury przemysłu zaawansowanych technologii, następuje wymiana informacji na niewyobrażalną dotąd skalę (np. miasta kreatywne) oraz kreacja kapitału intelektualnego. McLuhanowska koncepcja globalnej wioski oraz Harveyowska koncepcja kompresji czasu i przestrzeni uświadomiły nam, że czas i przestrzeń straciły swoje dawne znaczenie. Obecnie „bliżej” jest z miasta do miasta niż z miasta na wieś (McLuhan 1962, Harvey 1989). Takie procesy globalizacji, jak: rozwój wolnego rynku, telekomunikacji, nowoczesnych środków transportu czy korporacji transnarodowych 
zmieniły warunki brzegowe funkcjonowania przestrzeni miejskiej (Sala 2014a), a ich głównymi beneficjentami są wybrane miasta, centra wysokiej techniki czy przemysł nowej generacji, stanowiące węzły w globalnej sieci (Castels 1989, Robertson 1995, Czerny 2007, Wdowicka 2012, 2017).

Procesy globalizacji na terenie miast, metropolii lub obszarów metropolitalnych prowadzą do powstawania nowych struktur, takich jak: okręgi przemysłowe, bieguny technologii, parki technologiczne, centra innowacji czy inkubatory przedsiębiorczości (Benko 1993, Kukliński i in. 2000, Dziemianowicz, Łukomska 2009). Podstawowym motorem napędowym są korporacje transnarodowe. W wyniku działalności międzynarodowych firm, rozwój staje się bardziej punktowy niż powierzchniowy, a kształtujący się system sieciowy obejmuje swym zasięgiem głównie miasta, które pełnią rolę węzłów w globalnej sieci połączeń (Czerny 2007).

Procesy globalizacji stwarzają możliwości rozwoju, gdyż w ich wyniku, poprzez działalność korporacji transnarodowych, następuje transformacja miast (Czerny 2001, 2005). Powstają nowe struktury włączane w globalny system sieciowy. Procesy globalizacji w miastach niosą wiele tendencji, ich część znamy i jesteśmy ich świadomi, natomiast wielu procesów i ich skutków jeszcze sobie nie uzmysłowiliśmy (Sala 2014b).

Rozwój przestrzeni miejskiej miast wymaga wyważonych decyzji, które pozwoliłyby na uniknięcie negatywnych konsekwencji procesów globalizacji i wzmacniałyby pozytywne trendy. Pod wpływem procesów globalizacji zmienia się oblicze polskich miast. Następuje napływ zachodniego kapitału nastawionego na szybki zysk i jednocześnie zachodzi szybka erozja lokalnych tradycyjnych struktur gospodarczych. Współczesne miasta znajdują się w fazie walki o miejsce w hierarchii. Te, które tę walkę wygrają, będą się dynamicznie rozwijać, mając przed sobą dobre perspektywy, pozostałe ulegną stagnacji lub wręcz regresowi.

Współczesne miasta stają się też areną rywalizacji między lokalnymi społecznościami a neoliberalnymi tendencjami typowymi dla procesów globalizacji. Społeczności lokalne w Polsce mają wiele do nadrobienia w stosunku do zachodnich społeczeństw. W Polsce nowoczesny rozwój lokalny miast toczy się od momentu transformacji ustrojowej, w przeciwieństwie do miast zachodnich, które nie mają doświadczeń z systemu centralnie sterowanego i w których proces rozwoju zaczął się znacznie wcześniej.

\section{Etapy postępowania badawczego}

Przedmiotem badań są procesy globalizacji, należące do czynników najintensywniej zmieniających naszą rzeczywistość. Bez względu na nasze poglądy czy zapatrywania, procesy globalizacji, takie jak rozwój wolnego rynku, korporacji transnarodowych, telekomunikacji czy nowoczesnych środków transportu, wyznaczają współcześnie warunki brzegowe dla funkcjonowania poszczególnych państw. Procesy globalizacji nie determinują nowego ładu gospodarczego opartego na konkretnej ideologii. Można stwierdzić, że tworzą fundament, na którym 
kształtuje się nowy, jeszcze nieznany ład społeczny, gospodarczy czy polityczny zmieniający charakter poszczególnych krajów, regionów, miast i wsi.

Obiektem badań są Kielce - typowe 200-tysięczne, postindustrialne polskie miasto, które jest centrum będącego w fazie rozwoju obszaru metropolitalnego zamieszkanego przez ponad 300 tys. mieszkańców. Władze samorządowe podejmują wiele inicjatyw, mających na celu rozwój przestrzeni miejskiej Kielc.

Na rozwój przestrzenny Kielc istotny wpływ ma orografia. Kielce położone są w większości na obszarze Padołu Kielecko-Łagowskiego. Zarówno od wschodu, jak i zachodu utrudnieniem dla rozwoju są występujące działy wodne, wymuszające budowę przepompowni ścieków w celu połączenia nowych terenów inwestycyjnych z miejską siecią kanalizacyjną. Jeszcze trudniejsza sytuacja występuje w kierunku północnym oraz południowym. Od północy miejska zabudowa ograniczona jest ciągiem wzgórz pasma głównego Gór Świętokrzyskich, których deniwelacje dochodzą do $200 \mathrm{~m}$. Natomiast od południa rozciągają się wzgórza Pasma Dymińskiego, Posłowickiego oraz Zgórskiego, o deniwelacjach rzędu 100-150 m. Ciągi wzgórz na północy i południu blokują rozwój przestrzenny miasta. Niezależnie do tego niekorzystnego położenia, procesy globalizacji przyczyniają się do różnicowania mieszkańców Kielc. Szybko bogacąca się grupa kielczan stopniowo przemieszcza się z obszarów centralnych miasta na peryferie, często przekraczając bariery orograficzne i tworząc suburbia wewnętrzne i zewnętrzne.

Celem badania jest analiza zmian zachodzących pod wpływem procesów globalizacji w przestrzeni miejskiej Kielc. Aby go osiągnąć sformułowano następujące ogólne pytanie badawcze: jak procesy globalizacji zmieniają przestrzeń miejską w Kielcach oraz szczegółowe pytania badawcze:

1. Jaka jest dostępność komunikacyjna Kielc?

2. Czy procesy globalizacji przyczyniły się do transformacji gospodarczej Kielc?

3. Jakie zmiany zaszły w fizjonomii miasta pod wpływem procesów globalizacji?

4. Jaki wpływ miały korporacje handlowe na przestrzeń miejską Kielc?

5. Jakie nowoczesne i innowacyjne usługi powstały w przestrzeni miejskiej Kielc?

W trakcie badań wykorzystano pierwotne i wtórne źródła informacji. Dane pierwotne pochodzą bezpośrednio z przedsiębiorstw opisywanych $\mathrm{w}$ pracy, natomiast dane wtórne zebrano $z$ dostępnej literatury oraz opracowań Urzędu Miasta Kielce, Kieleckiego Parku Technologicznego czy Targów Kielce. Potem przystąpiono do opracowywania wyników. Analiza danych i wyników pozwoliła na uogólnienie zawarte w końcowych wnioskach.

W pracy zastosowano metodę analizy elementarnej (Runge 2006), w trakcie której starano się wyróżnić w przestrzeni miejskiej Kielc elementy rozwijające się pod wpływem procesów globalizacji.

W literaturze przedmiotu brakuje opracowań na temat relacji, jakie zachodzą między procesami globalizacji a rozwojem przestrzeni Kielc. Dlatego praca ta jest próbą wypełnienia owej luki. 


\section{Dostępność komunikacyjna}

Dostępność komunikacyjna ma kluczowe znaczenie dla rozwoju przestrzeni miejskiej Kielc. Miasto geograficznie usytuowane jest między Warszawą, Łodzią i Krakowem, co zapewnia stosunkowo łatwy dostęp do międzynarodowych lotnisk (Kraków - 126 km, Katowice - 139 km, Łódź - 147 km i Warszawa - 177 km). Jednak jakość połączeń drogowych jest niewystarczająca. W kierunku Warszawy jest dobra (dwupasmowa droga szybkiego ruchu E7), natomiast w kierunku Krakowa droga szybkiego ruchu kończy się na granicy województwa świętokrzyskiego, w województwie małopolskim trasa E7 nie jest priorytetowa. Istnieje również potrzeba skomunikowania Kielc z Łodzią, brakuje 100-kilometrowego odcinka trasy szybkiego ruchu do Piotrkowa, który pozwoliłby połączyć drogę $\mathrm{nr} 74 \mathrm{z}$ autostradą A1.

Jednym z podstawowych procesów globalizacji jest rozwój nowoczesnych środków transportu, do których zalicza się transport lotniczy, kontenerowy oraz szybką kolej (Sala 2014a). Kielce w nieokreślonej bliżej perspektywie mają zostać przyłączone do sieci szybkiej kolei. Obecnie linia kolejowa Warszawa-Kraków jest częściowo modernizowana i przystosowywana do średnich prędkości $(120 \mathrm{~km} / \mathrm{h})$, natomiast trwają wstępne prace nad połączeniem Kielc szybką koleją z Centralną Magistralą Kolejową.

Przez ostatnie lata w Kielcach trwała dyskusja, czy miastu potrzebne jest lotnisko. Efektem była decyzja o budowie lotniska w Obicach koło Kielc. Pomimo zaangażowania środków publicznych odstąpiono od realizacji tej inwestycji. Decyzja była kontrowersyjna i na pewno nie sprzyja rozwojowi miasta, a w szczególności znajdującego się w Kielcach drugiego ośrodka wystawienniczego w Europie Środkowo-Wschodniej, jakim są Targi Kielce. Istniejące lotnisko Kielce-Masłów, $z$ uwagi na komplikacje prawne i długość pasa startowego (900 m), nie jest perspektywiczne i obecnie pełni wyłącznie funkcje sportowe i turystyczne.

Oddalenie od sieci autostrad, szybkiej kolei oraz brak lotniska spowalnia rozwój przestrzeni miejskiej Kielc.

\section{Specyfika transformacji gospodarczej Kielc}

W czasach PRL-u miasto miało ograniczone możliwości kreowania własnego rozwoju. Wszelkie decyzje dotyczące produkcji w kieleckich zakładach podejmowane były centralnie $\mathrm{w}$ Warszawie. Zmiany $\mathrm{w}$ strukturze polskiego przemysłu nie sprzyjały rozwojowi ani miasta, ani poszczególnych firm. Często rezygnowano z produkcji jednych wyrobów, zastępując je innymi, jednocześnie wymagając od pracowników zupełnie innych umiejętności. Przykładem może być dawna Huta Ludwików, przemianowana kolejno na: Kieleckie Zakłady Wyrobów Metalowych Polmo SHL, w 1991 r. na Fabrykę Samochodów Specjalizowanych Polmo SHL, a w 1995 r. na Zakłady Wyrobów Metalowych SHL S.A. (Jastrzębski 2014). W tej fabryce produkowano m.in.: szable kawaleryjskie wzór 34, motocykle SHL, motocykle Gazela, pralki wirnikowe Frania czy szoferki do samochodów. Obecnie firma 
wykorzystuje procesy globalizacji i wchodzi w zależności sieciowe z takimi potentatami, jak: Volvo, CNH, Komatsu Utility European oraz Scania.

Chaotyczny rozwój kieleckiego przemysłu starano się uporządkować dopiero na początku XXI w. Wizja rozwoju została opisana w strategii rozwoju miasta na lata 2007-2020. Po wnikliwej analizie potencjału gospodarczego Kielc zwrócono uwagę na takie atuty miasta, jak: tradycje przemysłowe, dobrze wykształcone kadry, duża podaż pracowników, dobrze rozwinięte szkolnictwo na poziomie średnim i wyższym oraz duża sieć banków. W strategii zrezygnowano z powrotu Kielc jako ośrodka przemysłu ciężkiego, co było lansowane po 1945 r. oraz z lansowanej w latach 70. XX w. koncepcji Kielc jako ośrodka przemysłu budowlanego.

W czasie przemian ustrojowych po 4 czerwca 1989 r., podobnie jak w innych miastach, w Kielcach skończyło się socjalistyczne centralne planowanie. Przystąpiono do transformacji ustrojowej, polegającej na zmianie stosunków własności i chaotycznej prywatyzacji wielu zakładów przemysłowych. Podejmowano w tym czasie intensywne działania mające doprowadzić istniejące zakłady do upadku, aby następnie osoby związane z dawnym układem politycznym mogły przejąć firmy poniżej ceny rynkowej. Zgodnie z tzw. „planem Balcerowicza” prowadzono działania zmierzające do likwidacji przemysłu ciężkiego w mieście i rozbudowy przemysłu lekkiego i elektromaszynowego, przy powszechnym niezadowoleniu społecznym. W tym okresie inflacja osiągnęła 1000\% (1990 r.), co było powszechnie wykorzystywane przez spekulantów.

\section{Zmiany w fizjonomii przestrzeni miejskiej Kielc}

Kielce należą do miast niespójnych architektonicznie. W historycznym ujęciu występują elementy austriackie (rynek), rosyjskie (plac Wolności) i polskie (ul. Sienkiewicza). Dynamiczny rozwój Kielc przypada na lata powojenne, w którym to okresie budowano zgodnie z komunistycznymi koncepcjami. Pierwszymi okazałymi budowlami w latach 50. XX w. były: budynek Polskiej Zjednoczonej Partii Robotniczej oraz sienkiewiczowska dzielnica mieszkaniowa. W latach 60. XX w. zapadła rządowa decyzja o budowie w Kielcach dużego ośrodka przemysłowego z 200 tys. mieszkańców. W tym okresie zaczęły powstawać wielkie osiedla mieszkaniowe opasujące stare miasto. Do ciekawszych obiektów należy zaliczyć modernistyczną koncepcję hali widowiskowo-sportowej przy ul. Żytniej oraz wybudowany w miejscu dawnej dzielnicy żydowskiej gmach Prezydium Wojewódzkiej Rady Narodowej. W latach 70. XX w. powstały m.in. zabudowania Politechniki Świętokrzyskiej oraz wizytówka miasta, jaką jest kielecki dworzec autobusowy w kształcie spodka. Schyłek epoki komunizmu to z kolei niewydolność finansowa państwa i napięcia społeczne. W tym czasie $z$ wielkim trudem kończono rozpoczęte inwestycje budowlane i nie podejmowano nowych wyzwań. Dopiero upadek starego systemu i pojawienie się warunków rynkowych zaowocowały śmiałymi nowoczesnymi inwestycjami. Do pierwszych obiektów z tego okresu należały: budynek kieleckiego oddziału Narodowego Banku Polskiego, biurowiec 
Kolportera, Astra Park, budynek Biblioteki Uniwersytetu Jana Kochanowskiego czy Centrum Geoedukacji na Wietrzni.

Obecnie Śródmieście Kielc znalazło się jako całość w rejestrze zabytków ze względu na historyczny układ urbanistyczny, składający się z elementów przedlokacyjnych, średniowiecznych, barokowych i dziewiętnastowiecznych, budujących krajobraz miejski o najwyższych walorach widokowych.

$\mathrm{Na}$ peryferiach centrum występuje konflikt zabudowy wielkomiejskiej z zabudową małomiasteczkową. W ciągu głównych dróg tranzytowych na obszarze miasta realizowane są duże inwestycje napędzane trendami globalizacyjnymi, takie jak np. budynek Kolportera, Starostwa Powiatowego czy Pod Telegrafem, mające na celu wywarcie pozytywnego wrażenia na osobach będących przejazdem w Kielcach. Jednak dynamiczny rozwój miasta sprawił, że szczególnie na obrzeżach centrum (np. ul. Tarnowska) oraz w samym centrum (np. ul. Warszawska) istnieją okazałe budynki wybudowane przy starych niskich kamienicach będących typowym przykładem budownictwa małomiasteczkowego. Goście będący w wielu rejonach miasta mogą mieć problem z oszacowaniem jego skali i stwierdzeniem, czy są w dużym mieście czy małym miasteczku. Jednak fizjonomia Kielc ciągle się zmienia, upodabniając je do miast zachodnich.

\section{Korporacje handlowe jako czynnik zmian w przestrzeni miejskiej Kielc}

Jednym z głównych procesów globalizacji jest rozwój korporacji transnarodowych, a w omawianym przypadku korporacji handlowych. W Kielcach zgromadziły się głównie w Galerii Handlowej Echo (ponad 300 sklepów) oraz w Galerii Handlowej Korona (ponad 160 sklepów). Wraz z dynamicznym rozwojem obszarów peryferyjnych Kielc znajdujących się w dzielnicach Niewachlów oraz Czarnów korporacje handlowe zaczęły lokalizować swoje siedziby w zachodniej i północno-zachodniej części miasta. Powstanie nowych hipermarketów (łącznie $8 \mathrm{w} 2018$ r.) i supermarketów (łącznie 43) (tab. 1) zmieniło strukturę handlu w Kielcach. Ludność ograniczyła do minimum zakupy w małych osiedlowych sklepach, co było przyczyną upadku części z nich. W kolejnych latach zmienia się struktura dużych sklepów. Możemy zauważyć stagnację w rozwoju hipermarketów oraz domów towarowych i handlowych, jednocześnie dynamicznie zwiększa

Tabela 1. Sklepy według form organizacyjnych w Kielcach

\begin{tabular}{lrrrrrr}
\hline & 2014 & 2015 & 2016 & 2017 & 2018 & 2019 \\
\hline Hipermarkety & 7 & 8 & 8 & 8 & 8 & 9 \\
Supermarkety & 36 & 37 & 39 & 42 & 43 & 43 \\
Domy towarowe & 1 & 1 & 1 & 1 & 1 & 1 \\
Domy handlowe & 4 & 3 & 3 & 3 & 3 & 3 \\
\hline
\end{tabular}

Źródło: opracowanie własne na podstawie: Centrum Obsługi Inwestora UM Kielce. 
Tabela 2. Wybrane obiekty handlowe Kielc

\begin{tabular}{llc}
\hline \multicolumn{1}{c}{ Nazwa obiektu } & \multicolumn{1}{c}{ Deweloper } & Powierzchnia handlowa \\
\hline Galeria Echo & Echo Investment SA & 70 tys. $\mathrm{m}^{2}$ \\
Galeria Korona & Church Land Development & 34,1 tys. $\mathrm{m}^{2}$ \\
Pasaż Świętokrzyski & Echo Investment SA & 13,2 tys. $\mathrm{m}^{2}$ \\
Centrum Radomska & Metro & 37 tys. $\mathrm{m}^{2}$ \\
\hline
\end{tabular}

Źródło: opracowanie własne na podstawie: Centrum Obsługi Inwestora UM Kielce.

się liczba supermarketów. W latach 2014-2018 obserwujemy wzrost liczby supermarketów o ponad $16 \%$.

Korporacje handlowe $\mathrm{w}$ istotny sposób reorganizują przestrzeń miejską Kielc. Z jednej strony wprowadziły do miasta powiew świeżości i nowoczesności (budynki wielkopowierzchniowe wyraźnie odznaczają się $\mathrm{w}$ fizjonomii miasta), $\mathrm{z}$ drugiej strony są elementem obcym $\mathrm{w}$ architekturze, zaburzającym tradycyjne walory typowe dla Kielc.

W Kielcach znajduje się jedna $z$ największych w Polsce galerii handlowych Galeria Echo (www.propertydesign.pl), w której funkcjonuje ponad 300 sklepów. Razem z Galerią Korona (ponad 160 sklepów) zmieniły one strukturę handlu w centrum miasta (tab. 2). Galeria Echo zdominowała kielecki handel wielkopowierzchniowy zarówno pod względem liczby sklepów, jak i powierzchni (zajmuje ponad $45 \%$ powierzchni czterech głównych galerii kieleckich) (tab. 2, 3). Zasięg jej oddziaływania wykracza daleko poza Kielce i obejmuje takie miasta, jak np.: Skarżysko-Kamienna, Starachowice czy Ostrowiec Swiętokrzyski. Małe sklepy zlokalizowane $\mathrm{w}$ centrum miasta zaczęly przeżywać kryzys (wiele $\mathrm{z}$ nich musiało zostać zamkniętych). Z tradycyjnych koncentracji handlowych zostały tylko dwa obiekty przy głównym deptaku (ul. Sienkiewicza).

\section{Wybrane nowoczesne usługi dla biznesu}

Procesy globalizacji przyczyniają się do dynamicznego wzrostu powiązań pomiędzy uczestnikami rynku, co przejawia się w rozwoju rynku biurowego (Wdowicka 2011). Popyt na biura w miastach ma tendencję wzrostową, co pozytywnie wpływa na rynek budowlany. W 2019 r. najwięcej buduje się powierzchni biurowej w Warszawie $\left(730\right.$ tys. $\left.\mathrm{m}^{2}\right)$, Katowicach $\left(250\right.$ tys. $\left.\mathrm{m}^{2}\right)$, Wrocławiu $\left(210\right.$ tys. $\left.\mathrm{m}^{2}\right)$, Krakowie $\left(190\right.$ tys. $\left.\mathrm{m}^{2}\right)$, Trójmieście $\left(100\right.$ tys. $\left.\mathrm{m}^{2}\right)$ i Poznaniu (90 tys. $\left.\mathrm{m}^{2}\right)$ (biurainfo.pl). W Kielcach całkowita powierzchnia biur o najwyższym standardzie $\left(\right.$ klasa $\mathrm{A}+$ ) lub wysokim standardzie (klasa $\mathrm{B}+$ ) wynosi 63 tys. $\mathrm{m}^{2} \mathrm{i}$ jest zlokalizowana w 21 budynkach, a w budowie jest kolejne 24 tys. $\mathrm{m}^{2}$, które będą zlokalizowane w jednym budynku (tab. 4). Jednak aż 59\% nowoczesnej powierzchni biznesowej zlokalizowane jest w dwóch obiektach (Kieleckie Centrum Biznesu 
Tabela 4. Wybrane obiekty biurowe w Kielcach klasy A, B+ i B

\begin{tabular}{lrll}
\hline \multicolumn{1}{c}{ Nazwa budynku } & \multicolumn{1}{c}{ Powierzchnia } & \multicolumn{1}{c}{ Właściciel } & \multicolumn{1}{c}{ Przykładowi najemcy } \\
\hline Kieleckie Centrum & 21 tys. $\mathrm{m}^{2}$ & Kieleckie Centrum & Call Center Inter Galactica, \\
Biznesu & & Biznesu & Medicover, PKP Informatyka \\
Astra Park & 16,2 tys. $\mathrm{m}^{2}$ & Echo Investment & Barlinek, Cersanit, Echo Investment \\
Kolporter Tower & 7,6 tys. $\mathrm{m}^{2}$ & Kolporter & Kolporter \\
Telegraf City & 5 tys. $\mathrm{m}^{2}$ & Pod Telegrafem & KIK, Pod Telegrafem \\
Ventus Apollo Business & 5 tys. $\mathrm{m}^{2}$ & Apolloplast & \\
Aqua & 5 tys. $\mathrm{m}^{2}$ & Aqua & Redakcja Echa Dnia \\
Apollo VIP & 6 tys. $\mathrm{m}^{2}$ & Apolloplast & \\
Apollo Split & 4,5 tys. $\mathrm{m}^{2}$ & Apollopkast & \\
\hline
\end{tabular}

Źródło: opracowanie własne na podstawie: www.outsourcing.pl

oraz Astra Park) (tab. 4). Całkowite zasoby nowoczesnej powierzchni biurowej w Kielcach są na poziomie $13 \%$ w stosunku do Łodzi, 12\% - Poznania czy $11 \%$ - Katowic (ryc. 1).

Pod względem całkowitej powierzchni biurowej w Polsce wyraźnie dominują duże miasta, jednak Kielce, w miarę swoich możliwości, starają się zaistnieć na omawianym rynku (ryc. 1). Faktem jest, że Kielce nie są w stanie konkurować $z$ dużymi polskimi miastami, ale przez świat biznesu są uważane za jeden $z$ wiodących perspektywicznych ośrodków, dysponujących dużym potencjałem w zakresie nowoczesnych usług. Wraz ze Szczecinem, Lublinem i Bydgoszczą Kielce zostały uznane pod względem posiadania wielkopowierzchniowych powierzchni biurowych za rynki rozwijające się. Miasto dysponujące przewagą kosztową uzupełnia większe aglomeracje miejskie w dziedzinie nowoczesnych usług dla

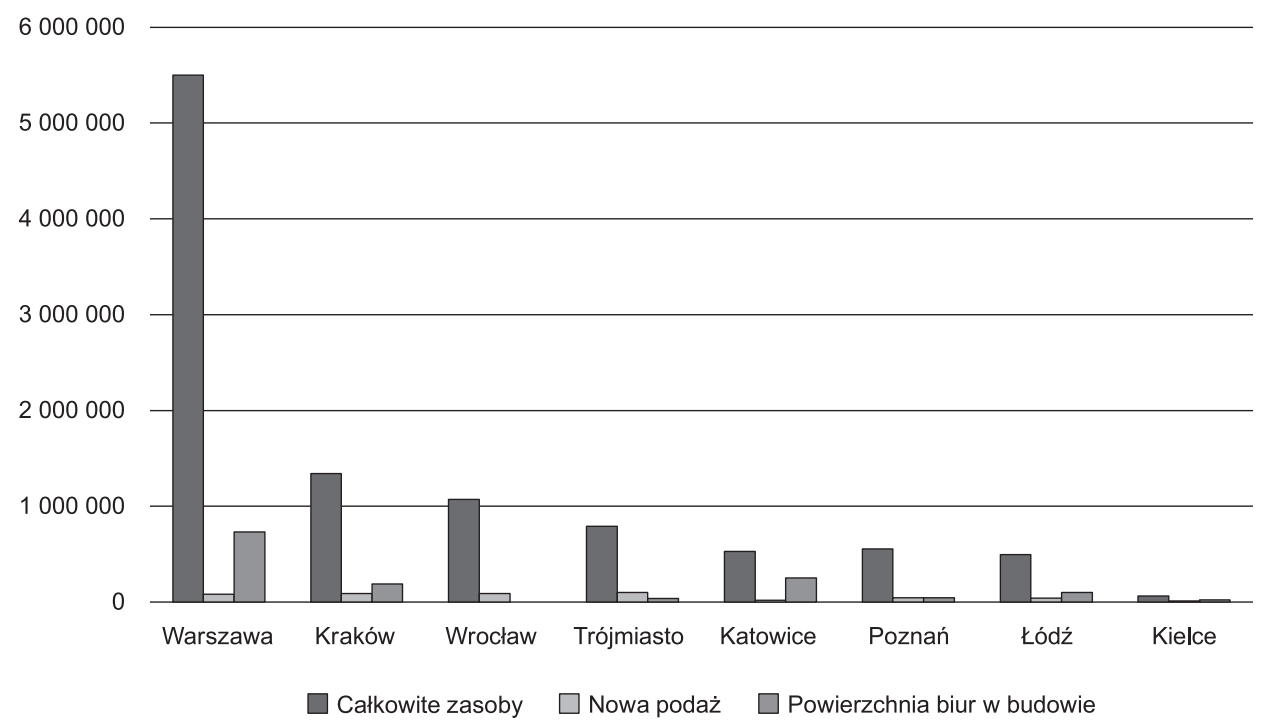

Ryc. 1. Powierzchnia biurowa Kielc na tle największych miast polskich w $2019 \mathrm{r}$.

Źródło: opracowanie własne na podstawie e-gospodarka.pl. 
biznesu, obejmujących: outsourcing IT, outsourcing procesów biznesowych (BSS - Business Suppotr Solution), centra usług wspólnych (SSC - Shared Services Center) oraz badania i rozwój. Dynamiczny rozwój miasta sprawił, że swoje centra usługowe ulokowały tu takie znane marki, jak Medicover czy Comarch.

Uzupełnieniem powierzchni biurowych jest nowoczesna gospodarka magazynowa. Sektor magazynowy rozwija się w Polsce bardzo dynamicznie, a poprawa infrastruktury komunikacyjnej sprzyja lokowaniu magazynów w mniejszych miejscowościach, położonych z dala od dużych polskich miast (Warszawa, Kraków, Łódź, Poznań, Wrocław, Gdańsk), będących motorem wzrostu gospodarczego i przyciągających najwięcej inwestycji. Kielce usytuowane są na uboczu głównych szlaków tranzytowych Polski. W związku z powyższym nowoczesna gospodarka magazynowa jest w fazie wstępnej, jednak miasto postrzegane jest jako wschodząca gwiazda rynku magazynowego ze względu na posiadane atuty (magazyny. pl). W 2019 r. funkcjonowały w nim dwa nowoczesne obiekty magazynowe (Panattoni Park Kielce o powierzchni 48,7 tys. $\mathrm{m}^{2}$ oraz 7R Park Kielce $-22,7$ tys. $\mathrm{m}^{2}$ ). Całkowita powierzchnia magazynowa wynosi 71,5 tys. $\mathrm{m}^{2}$, w budowie znajduje się 52,2 tys. $\mathrm{m}^{2}$, a planowane jest kolejne 16,5 tys. $\mathrm{m}^{2}$ (invest.kielce.pl).

\section{Nowoczesne powierzchnie wystawiennicze}

Otwarcie poszczególnych krajów na międzynarodową konkurencję wymusza współpracę ekonomiczną w celu osiągnięcia przewagi konkurencyjnej. Pozyskiwanie kontaktów biznesowych odbywa się często na obszarze powierzchni wystawienniczych. W Kielcach od 1992 r. istnieje silny ośrodek wystawienniczy - Targi Kielce. Obecnie pod względem liczby zwiedzających kieleckie targi są drugim centrum wystawienniczym w Europie Środkowo-Wschodniej (po targach poznańskich) oraz trzecim pod względem wynajmowanej powierzchni (tab. 5, 6). Tym samym wyprzedziły m.in. takie wystawy, jak: węgierskie Hungeexpo, czeskie BVV Trade Fairs Brno czy ukraińskie Kyiv International Contract. Oferta targowa jest bardzo bogata - rocznie odbywa się ponad 70 imprez targowych oraz około 700 różnego typu konferencji. Swoje produkty wystawia około 6 tys. wystawców z 56 krajów świata. Targi przyciągają około 275 tys. gości. Całkowita powierzchnia targów wynosi 90 tys. $\mathrm{m}^{2}$.

Jak wynika z tabeli 5, w okresie 2005-2018 liczba wystaw zwiększyła się o $61 \%$, podobnie obserwujemy wzrost liczby wystawców (47\%). W badanym okresie najbardziej wzrosła powierzchnia udostępniona dla wystawców (112\%), co świadczy o dużym, wciąż wzrastającym zainteresowaniu wystawców. Liczba odwiedzających utrzymuje się na podobnym poziomie z niewielkimi fluktuacjami w przedziale między 207826 (2005) a 215736 (2018) - wzrost o 4\%.

Jednym z najważniejszych wydarzeń na mapie światowych targów przemysłu obronnego jest Międzynarodowy Salon Przemysły Obronnego na Targach Kielce (MSPO). Od 2014 r. MSPO towarzyszą wystawy narodowe, pośród których drugi raz wybrano Stany Zjednoczone, prezentujące tutaj m.in. myśliwiec piątej generacji F-35, nad którego zakupem zastanawia się polski rząd. W 2019 r. ponad 
Tabela 5. Dynamika podstawowych wskaźników rozwoju Targów Kielce (2005-2018)

\begin{tabular}{lccccc}
\hline & & & & \multicolumn{2}{c}{ Odwiedzający } \\
\cline { 5 - 6 } Rok & $\begin{array}{c}\text { Liczba } \\
\text { wystaw }\end{array}$ & $\begin{array}{c}\text { Liczba } \\
\text { wystawców }\end{array}$ & $\begin{array}{c}\text { Wynajęta po- } \\
\text { wierzchnia }\left[\mathrm{m}^{2}\right]\end{array}$ & Liczba w tys. & $\begin{array}{c}\text { Zmiana rok do } \\
\text { roku w \% }\end{array}$ \\
\hline 2005 & 31 & 3819 & 85068 & 207826 & x \\
2006 & 29 & 4000 & 95254 & 118934 & $-42,7$ \\
2007 & 38 & 4744 & 127798 & 182786 & 53,0 \\
2008 & 43 & 5455 & 157443 & 153757 & $-15,8$ \\
2009 & 46 & 5311 & 155588 & 169367 & 10,1 \\
2010 & 54 & 5668 & 154213 & 196609 & 16 \\
2011 & 52 & 6370 & 183212 & 211295 & 7,5 \\
2012 & 50 & 5602 & 180070 & 215736 & 2,1 \\
2013 & 49 & 6008 & 174740 & 216840 & 0,5 \\
2014 & 47 & 6383 & 180343 & 209098 & $-3,6$ \\
2015 & 44 & 6490 & 214287 & 221198 & 5,7 \\
2016 & 55 & 7589 & 254860 & 248452 & 12,3 \\
2017 & 46 & 6942 & 248424 & 257983 & 3,8 \\
2018 & 50 & 5602 & 180070 & 215736 & $-16,3$ \\
\hline
\end{tabular}

Źródło: opracowanie własne na podstawie www. targikielce.pl.

50 amerykańskich korporacji zaprezentowało swoje produkty w ramach MSPO. Oprócz przedstawicieli Departamentu Obrony USA, kilkudziesięciu żołnierzy US Army, w targach uczestniczyły jedne z największych koncernów o globalnym zasięgu, takie jak: Lockheed Martin, Boeing czy Northrop Grumman. Ponadto

Tabela 6. Podstawowe dane tyczące hal wystawowych i sal konferencyjnych Targów Kielce

\begin{tabular}{lccc}
\hline & $\begin{array}{c}\text { Powierzchnia } \\
\text { brutto }\left(\mathrm{m}^{2}\right)\end{array}$ & Liczba miejsc & $\begin{array}{c}\text { Wymiary (długość } \\
\text { i szerokość) (w m) }\end{array}$ \\
\hline Hala A & 5100 & 3400 & $72 \times 72$ \\
Hala B & 5320 & 3550 & $72 \times 72$ \\
Hala C & 5430 & 3620 & $72 \times 72$ \\
Hala D & 5220 & 3480 & $72 \times 72$ \\
Hala E & 5355 & 4500 & $126 \times 44$ \\
Hala F & 4300 & 2870 & $72 \times 60$ \\
Hala G & 4250 & 2900 & $72 \times 60$ \\
Sala Alfa & 170 & 130 & $9,9 \times 17,2$ \\
Sala Omega & 418 & 572 & $20,4 \times 20,5$ \\
Sala Beta & 165 & 120 & $11 \times 15$ \\
Sala Gamma & 165 & 120 & $11 \times 15$ \\
Sala Delta & 137 & 120 & $11 \times 12,5$ \\
Sala Teta & 137 & 120 & $20,4 \times 42,9$ \\
Sala Alfa \& Omega & 875 & 900 & $23 \times 31,8$ \\
Sala Beta \& Gamma \& Delta & 731 & 400 & \\
\& Teta & & &
\end{tabular}

Źródło: opracowanie własne na podstawie: www.targikielce.pl. 
wśród międzynarodowych wystaw można wymienić: Agrotech - Międzynarodowe Targi Techniki Rolniczej, Autostrada Polska - Międzynarodowe Targi Budownictwa Drogowego i Enex - Międzynarodowe Targi Energetyki.

Działalność Targów Kielce nie ogranicza się tylko do obszaru Polski. Od 2016 r. wraz z ukraińskim Gal-Expo kielecki ośrodek organizuje EuroAgro - Międzynarodowe Targi Techniki Rolniczej we Lwowie, a od 2018 r. targi rowerowe Bike-Expo (www.targikielce.pl). Bogata oferta wystawiennicza nie byłaby możliwa, gdyby nie bardzo dobra infrastruktura Targów, dysponujących 6 halami wystawienniczymi o łącznej powierzchni $34975 \mathrm{~m}^{2}$ oraz sześcioma halami o zmiennej konfiguracji powierzchni (tab. 6).

Targi Kielce są też organem wiodącym klastra Grono Targowe Kielce, zrzeszającego 89 podmiotów powiązanych biznesowo. Sieciowa struktura obejmuje m.in. firmy z sektora usług wystawienniczych, poligraficznych, hotelarskich, a także kultury, sportu i promocji.

\section{Kielecki Park Technologiczny}

Bezpośrednia konkurencja krajowa i międzynarodowa między miastami wymusza pogoń za ciągle zmieniającymi się gustami i potrzebami konsumentów. Problemem staje się przekuwanie globalnych trendów w lokalne sukcesy. Jednym $z$ takich miejsc w Kielcach jest Kielecki Park Technologiczny. Jego początki sięgają 2006 r., kiedy to z inicjatywy Urzędu Miasta powstał dokument „Strategia dla miasta Kielce na lata 2007-2020”. Początkowo w 2017 r. uruchomiono projekt pt. „Kielecki Inkubator Technologiczny”, a w 2008 r. stworzono Kielecki Park Technologiczny. Obecnie Park zajmuje siedem budynków o łącznej powierzchni użytkowej około 29 tys. $\mathrm{m}^{2}$. W Parku zatrudnione są 42 osoby, które obsługują ponad 160 firm, w przeważającej części z polskim kapitałem. Jednak na terenie Parku działalność prowadzą także firmy z kapitałem zagranicznym, głównie z Niemiec, Francji, Niderlandów, Szwajcarii czy Skandynawii. Park oferuje szeroki zakres nowoczesnych usług dla biznesu. Oprócz terenów inwestycyjnych przykładowo można wymienić: specjalną strefę ekonomiczną, zespół laboratoriów technologicznych czy energetyczne centrum nauki. Jednym z głównych kierunków działalności jest rozwój start-upów, mających za zadanie kreowanie nowych produktów w warunkach ryzykownych. Młodzi kreatywni ludzie uzyskują szansę na przekuwanie swoich pomysłów $\mathrm{w}$ innowacyjny biznes. Oferując szeroki zakres usług doradczych, Park pomaga zweryfikować pomysł biznesowy oraz pozyskać źródła finansowania. W latach 2016 i 2017 najbardziej zaawansowane start-upy (34 firmy), po okresie inkubacji, otrzymały bezzwrotną dotację z Programu Operacyjnego Polska Wschodnia w wysokości do 800 tys. zł (technopark.kielce.pl). 


\section{Idea smart city - droga do inteligentnego miasta}

Jednym z głównych procesów globalizacji jest rozwój telekomunikacji, prowadzący do powstania społeczeństwa informacyjnego (Sala 2014). Kielecką egzemplifikacją rewolucji informatycznej jest realizowana od kilku lat idea smart city - zrównoważonego miasta inteligentnego. Projekt miasta innowacyjnego jest organizowany przez Urząd Miasta w porozumieniu z Uniwersytetem Jana Kochanowskiego oraz Politechniką Świętokrzyską. Koncepcja wymusza zmianę zarządzania miastem z podejścia sektorowego na zintegrowane. Łącząc dorobek nauki z technologiami informacyjno-komunikacyjnymi, tworzy się portal mający za zadanie zwiększenie efektywności zarządzania w celu poprawy jakości życia mieszkańców. Realizacja potrzeb miasta ma ogniskować się na obecnym i przyszłym pokoleniu, przy zachowaniu i poszanowaniu wysoko cenionych wartości gospodarczych, społecznych i przyrodniczych. W 2017 r. Kielce, jako pierwsze miasto $\mathrm{w}$ Polsce, uzyskało certyfikację na najwyższym, platynowym poziomie w zakresie zgodności z normą ISO37120 „Zrównoważony rozwój społeczny wskaźniki usług miejskich i jakości życia”, przyznawaną przez World Council on City Data z siedzibą w Toronto.

Podstawowym celem projektu jest stworzenie możliwości zarządzania miastem w oparciu o zestandaryzowane dane na bieżąco aktualizowane. Wypracowane wskaźniki zamieszczone na platformie są dostępne nie tylko dla wąskiej grupie specjalistów, ale także dla mieszkańców miasta (www.idea.kielce.eu). Dostęp mieszkańców do bazy danych umożliwia przeprowadzenie szerokich konsultacji społecznych oraz planowanie i realizację budżetu obywatelskiego. W demokratycznym procesie mieszkańcy podejmują decyzje dotyczące kierunków rozwoju miasta. Wspólne podejmowanie decyzji przez mieszkańców miasta i radnych sprzyja procesom decentralizacji władzy oraz promuje innowacyjność i przedsiębiorczość.

\section{Zarys wybranych czynników wzrostu lokalnego Kielc}

Jednym z motorów napędowych rozwoju miasta są kieleckie wyższe uczelnie. Spośród 12 uczelni wyższych na uwagę zasługują dwie uczelnie publiczne: Uniwersytet Jana Kochanowskiego oraz Politechnika Świętokrzyska. Wspólnie realizują projekt pt.: „Rozwój bazy badawczej specjalistycznych laboratoriów uczelni publicznych regionu świętokrzyskiego". Przedmiotem projektu jest modernizacja laboratoriów nastawionych na prowadzenie nowoczesnych badań, istotnych z punktu widzenia gospodarki narodowej. Projekt umożliwi prowadzenie badań podstawowych oraz stosowanych w zakresie nauk technicznych, fizycznych, biologicznych czy medycznych oraz przyczyni się do pogłębienia integracji kieleckiego środowiska naukowego.

Pośród licznych kieleckich powiązań międzynarodowych na uwagę zasługuje klub sportowy PGE Vive Kielce, siedemnastokrotny mistrz Polski w piłce ręcznej mężczyzn, zwycięzca Ligi Mistrzów w 2016 r. i czterokrotny uczestnik Final Four. Klub jest promotorem miasta i oprócz Targów Kielce jednym z głównych 
kreatorów marki Kielce, ponieważ za granicami Polski marka Vive jest słabo rozpoznawalna, natomiast kielecka drużyna znana jest po nazwą Kielce. Na rynku handballowym Kielce znane są w całej Europie i dołączyły do takich potęg (marek), jak: Barcelona, Paris Saint-Germain, Vesprem czy Kiel. Czterotysięczna Hala Legionów nie pozwala na przyjęcie wszystkich kibiców piłki ręcznej, karnety są od wielu lat wyprzedawane, a wśród chętnych do oglądania meczów Vive, oprócz Polaków, jest wiele osób zza granicy - głównie Czech, Słowacji, Ukrainy i Węgier.

O rozwoju Kielc w dużej mierze decydują kieleccy biznesmeni. Jednym z nich jest Michał Sołowow, według rankingu „Forbes” najbogatszy Polak, którego majątek szacowany jest na 15 mld $624 \mathrm{mln}$ zł. Działalność kieleckiego biznesmena oparta jest na wykorzystywaniu światowych trendów globalizacyjnych (dotychczas stworzył ok. 28 start-upów), w których wdraża innowacyjne pomysły. Jego biznes jest skoncentrowany wokół trzech kieleckich korporacji, tj. Synthos - działający w branży chemicznej, Barlinek - czołowy producent podłóg drewnianych w Polsce oraz Cersanit - producent płytek i ceramiki sanitarnej. Ponadto biznesmen jest zaangażowany w przemysł energetyczny i zielone technologie. Jego marzeniem jest wybudowanie w Polsce pierwszej elektrowni atomowej (www.forbes.pl).

\section{Podsumowanie}

Z badań wynika, że dostępność komunikacyjna Kielc jest niewystarczająca. Potrzebne są dalsze nakłady finansowe, żeby miasto było lepiej skomunikowane z sąsiednimi miastami, co pozwoli na potencjalne większe zainteresowanie nim wielkiego kapitału. Transformacja gospodarcza Kielc dokonana po 1989 r. pozwoliła im stać się nowoczesnym miastem. Zlikwidowano przemysł ciężki, w miejsce którego zaczęły powstawać usługi. Zasadniczo zmieniła się fizjonomia miasta. Obserwowane zmiany w fizjonomii przestrzeni miejskiej Kielc są efektem w dużej mierze funduszy europejskich. Powstawanie nowych atrakcyjnych budynków zgodnie z najnowszymi trendami stopniowo upodabnia Kielce do miast zachodnich. Zgodnie ze współczesnymi koncepcjami architektonicznymi w Kielcach zaczęto wznosić budynki o nowoczesnych formach i dużej powierzchni. Korporacje handlowe znacznie unowocześniły miasto. Wielkie sieci handlowe tworzą grupę głównych inwestorów, z jednej strony ożywiły one i unowocześniły lokalny handel, z drugiej strony stwarzają zagrożenie dla tradycyjnych, lokalnych przedsiębiorstw.

Reasumując, należy stwierdzić, że poprzez kreację kapitału intelektualnego, innowacyjnego, poprawę infrastruktury oraz wciąganie obywateli w procesy decyzyjne w Kielcach stopniowo rozwijają się funkcje globalne. Powstają nowe, atrakcyjne inwestycje, zmieniające fizjonomię miasta oraz warunki egzystencji. Kielce, wykorzystując międzynarodowe trendy, uległy licznym przekształceniom sprawiającym, że miasto jest atrakcyjne dla małych i średnich projektów BSS, natomiast rozwój Targów Kielce, Kieleckiego Parku Technologicznego oraz szkolnictwa wyższego sprawia, że rozwój miasta dąży do dostosowania struktury przestrzennej i gospodarczej do współczesnych wymagań gospodarki globalnej. 


\section{Literatura}

Benko G. 1993. Geografia technopolii. PWN, Warszawa.

Castells M. 1989. The informational city. Information technology, economic restructuring, and the urban regional process. Basic Blackwell Publishers, Oxford.

Czerny M. 2001. Globalizacja a rozwój lokalny w geografii społeczno- ekonomicznej. [W:] H. Rogacki (red.), Koncepcje teoretyczne i metody badań geografii społeczno-ekonomicznej i gospodarki przestrzennej. Bogucki Wydawnictwo Naukowe, Poznań.

Czerny M. 2005. Globalizacja a rozwój. Wybrane zagadnienia z geografii społeczno-gospodarczej świata. Wydawnictwo Naukowe PWN, Warszawa.

Czerny M., Łuczak R., Makowski J. 2007. Globalistyka. Procesy globalne i ich lokalne konsekwencje. Wydawnictwo Naukowe PWN, Warszawa.

Dziemianowicz W., Łukomska J. 2009. Bieguny wzrostu, ośrodki centralne i metropolie - gdzie jesteśmy i dokąd zmierzamy? [W:] Z. Makieła (red.), Potencjalne metropolie ze szczególnym uwzględnieniem Polski wschodniej. Studia KPZK PAN, t. 122.

Gorzelak G. 2009. Fakty i mity rozwoju regionalnego. Studia Regionalne i Lokalne, 2.

Harvey D. 1989. Condition of postmodernity. Basil Blackwell, Oxford.

Jastrzębski C. 2014. Gospodarka Kielc w latach 1970-2011. [W:] Adamczyk (red.), Kielce przez stulecia. Wyd. Jedność, Kielce.

Kukliński A., Kołodziejski J., Markowski T., Dziemianowicz W. 2000. Globalizacja polskich metropolii. Europejski Instytut Rozwoju Regionalnego i Lokalnego, Warszawa.

Mcluhan, M. 1962. The Gutenberg Galaxy: the making of typographic man. University of Toronto Press, Toronto.

Robertson R. 1995. Glocalization: Time-space and homogeneity-heterogeneity. [W:] M. Featherstone, S. Lash, R. Robertson (red.), Global modernities. Sage Publications, London.

Runge J. 2006. Metody badań w geografii społeczno-ekonomicznej. Uniwersytet Śląski, Katowice.

Sala S. 2014a. Procesy globalizacji. Istota i geograficzne implikacje. Instytut Geografii UJK, Kielce.

Sala S. 2014b. Konsekwencje procesów globalizacji. Instytut Geografii UJK, Kielce.

Wdowicka M. 2011. Innowacyjne przestrzenie w miastach w dobie globalizacji. Rozwój Regionalny i Polityka Regionalna, 15.

Wdowicka M. 2012. Miasta w dobie globalizacji. Korporacje transnarodowe w Polskich miastach a dostępność nowoczesnej przestrzeni dla biznesu. Studia Miejskie, 5.

Wdowicka M. 2017. Miasta w globalnej sieci korporacji transnarodowych. Uniwersytet im. Adama Mickiewicza, Poznań.

\section{Strony internetowe}

www.e-gospodarka.pl (dostęp: 1.03.2020)

www.forbes.pl (dostęp: 10.03.2020)

www.idea.kielce.eu (dostęp: 15.03.2020)

www.invest.kielce.pl (dostęp: 1.03.2020)

www.magazyny.pl (dostęp: 1.03.2020)

www.technopark.kielce.pl (dostęp: 8.02.2020)

www.propertydesign.pl (dostęp: 24.02.2020)

www.targikielce.pl (dostęp: 4.02.2020)

\section{The impact of globalization processes on changes in the urban space of Kielce}

Abstract: One of the main factors conditioning the development of modern cities are globalization processes. On the one hand, they increasingly link global trends with local issues, while on the other, they eliminate certain areas from the mainstream of development. This paper presents initiatives taken in Kielce under the influence of these processes. The introductory chapters present the spe- 
cifics of Kielce's economic transformation and changes in the city's physiognomy as a consequence of removing economic and physiognomy barriers with the outside world. Then, the development of commercial corporations, modern business services, modern exhibition space and Kielce Technology Park, which are examples of glocalization, were discussed.

Key words: globalization, globalization processes, local development, socio-economic development, Kielce 